\title{
LEGALITAS KEWENANGAN BADAN ARBITRASE NASIONAL INDONESIA DALAM PENERAPAN PRINSIP COMPETENCE-COMPETENCE
}

\author{
Wiratami ${ }^{1}$
}

${ }^{1}$ Fakultas Hukum Universitas Udayana, E-mail: wiratami.sh@gmail.com

\begin{tabular}{lr}
\hline Info Artikel & \\
\hline Masuk: & \\
Diterima : & \\
Terbit : & \\
& \\
Keywords $\quad$ Arbitration \\
Agreement, $\quad$ BANI \\
Regulations, $\quad$ Arbitration \\
Disputes \\
\\
\\
\end{tabular}

\begin{abstract}
According to the doctrine of the principle of competencecompetence, the arbitration board has jurisdiction to declare itself whether he has the authority to hear and decide on arbitration disputes. What is meant by the determination of jurisdiction is related to the validity of the arbitration clause and the validity of an agreement. The arbitral tribunal has the authority to evaluate or determine the validity of the arbitration agreement or the validity of the arbitration clause if the parties dispute the matter. The principle of competence-competence is one of the principles regarding the jurisdiction of this arbitration board that has been generally and widely accepted as a principle doctrine in international trade arbitration. This principle is one of the principles regarding the jurisdiction of arbitration board that have been widely accepted and generally as a principle in international commercial arbitration.
\end{abstract}

The legal problems in this research relate to the norm vacancies regarding the competence-competence principle in Law No. 30 of 1999 concerning Arbitration and Alternative Dispute Resolution (hereinafter abbreviated as AAPS Law).Solving research problems using normative legal methods with a legal approach, cases, and analysis of legal concepts.

The results of this reseach that (1) The Indonesian National Arbitration Board has been regulated in article 1 point 8 of the Arbitrtion Law and Alternative Dispute Resolution juncto article 31. (2) The provisions of article 18 paragraph 1 of the rules of the Indonesian National Arbitration Board can be used as the legality of authority in determining the validity of the arbitration agreement, if the agreement of the parties "is not null and void" or is considered to have never existed in its entirety.

\footnotetext{
Abstrak

Menurut doktrin prinsip comptence-competence, arbitrase mempunyai jurisdiksi didalam menyatakan sendiri apakah arbitrase tersebut mempunyai kewenangan untuk mendengarkan dan memutuskan sengketa arbitrase. Penentuan kewenangan arbitrase terkait dengan keabsahan suatu klausul arbitrase maupun perjanjian arbitrase apabila mereka yang membuat perjanjian mempersoalkan mengenai hal itu.Doktrin prinip competence-competence ini merupakan satu dari sekian
} 


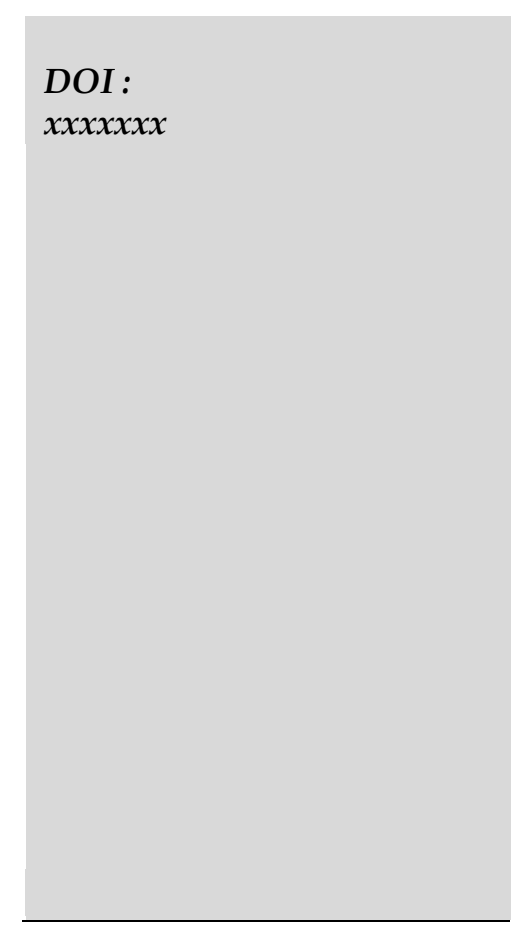

prinsip mengenai jurisdiksi arbitrase. Doktrin prinsip ini telah dikenal luas sebagai doktrin prinsip dalam arbitrase perdagangan internasional.

Permasalahan hukumnya berkaitan dengan adanya kekosongan norma hukum mengenai prinsip competence-competence dalam Undang-Undang Nomor 30 tahun 1999 tentang Arbitrase dan Alternatif Penyelesaian Sengketa (selanjutnya disebut UU AAPS). Penelitian ini menggunakan metode hukum normatif dengan pendekatan perundang-undangan, kasus dan analisa konsep hukum.

Hasil dari penelitian ini bahwa (1) BANI telah diatur dalam ketentuan Pasal 1 angka 8 UU AAPS juncto Pasal 31. (2) Ketentuan Pasal 18 ayat (1) Peraturan BANI dapat dijadikan landasan legalitas kewenangan BANI dalam menentukan keabsahan perjanjian arbitarse, apabila perjanjian para pihak untuk menyelesaikan sengketa melalui arbitrase tidak "batal demi hukum" atau dianggap tidak pernah ada secara keseluruhan.

\section{Pendahuluan}

Hal penentuan wewenang oleh badan arbitrase lazim disebut dengan doktrin competence-competence. Badan arbitrase dapat menentukan dirinya sendiri sebagai badan atau pihak yang berwenang mengenai hal-hal apa saja yang menjadi kewenangan kompetensinya, berdasarkan kewenangan yang lahir dari penunjukan para pihak. ${ }^{1}$ Perkembangan lebih lanjut, doktrin competence-competence ini telah pula dijadikan sebagai prinsip dasar dalam modern law arbitration yang menentukan bahwa pengadilan arbitrase berwenang untuk menentukan yurisdiksi atau kompetensinya sendiri, oleh karena itu sudah semestinya bahwa lembaga pertama yang berhak menyatakan bahwa arbitrase itu berwenang adalah arbitrase bukan pengadilan. ${ }^{2}$ Lebih lanjut, William Park sebagaimana dikutip oleh Huala Adolf, mengatakan bahwa di dalam doktrin competence-competence terkandung pengertian bahwa badan arbitrase dapat memeriksa masalah kewenangannya sendiri tanpa harus menunggu kepastian pengadilan, ${ }^{3}$ sebab sebagaimana dikemukakan oleh Alan Redfern dan Martin Hunter bahwa the power of an arbitral tribunal to decide upon its on jurisdiction is refered to above as an "inherent" power. 4

Pendapat serupa juga dikemukakan oleh M. Husseyn Umar bahwa dengan adanya klausula arbitrase maka yang berkompeten adalah arbitrase, jadi negara tidak boleh ikut campur tangan, karena baik pengadilan maupun arbitrase mempunyai pengaturan sendiri-sendiri, dan meskipun salah satu pihak mengajukan perkara ke

${ }^{1}$ Adolf, Huala. (2014). Sengketa Penanaman Modal : Yurisdiksi Badan Arbitrase ICSID. Arbitration Newsletter BANI. Vol 6 No. 1. Jakarta : March 2014, p. 29. Pengertian kompeten yang dimaksud adalah A court's power to decide a case or issue a decree. (2009) Black's Law Dictionary. Standard Ninth Edition, p.927

2 Memi, Cut. (2017). Arbitrase Komersial Internasional Penerapan Klausul dalam Putusan Pengadilan Negeri. Jakarta : Sinar Grafika, p. 42-43

${ }^{3}$ Park, William. (1997). When and Why Arbitration Matters. dalam Hartwell, M. Beresford, Geofrey (ed). (1997).The Commercial Way to Justice, p.86

${ }^{4}$ Redfern, Alan and Hunter. ( 2004 ). Law and Practice of International Commercial Arbitration (Fourth Edition), Sweet \& Maxwell,p.300 
pengadilan, proses arbitrase tetap berjalan terus. ${ }^{5}$ Demikian pula, hal yang tidak jauh berbeda dikemukakan oleh Margaret L. Moses sebagaimana dikutip Huala Adolf bahwa salah satu doktrin yang paling penting dan berpengaruh terhadap pengaturan atau perkembangan arbitrase adalah doktrin Competenz-Competenz (Competence-Competence). Doktrin ini menyatakan bahwa para majelis arbitrase sendiri-lah yang menentukan apakah dirinya berwenang atau tidak untuk menangani sesuatu sengketa. Margaret L. Moses mengartikan doktrin competence-competence ini sebagai : arbitrators are competent to determine their own competence, that is, they are empowered to decide their own jurisdiction to hear and determine the dispute berofe them. 6

Setiawan, seorang mantan hakim Mahkamah Agung mengatakan bahwa arbitration clause merupakan dasar pijakan serta dasar kewenangan bagi para arbiter untuk memeriksa serta memutus perkaranya. ${ }^{7}$ Dapat tidaknya suatu perkara dibawa untuk diselesaikan melalui lembaga non litigasi seperti melalui arbitrase ditentukan dari ada tidaknya arbitration clause atas dasar adanya kontrak tertulis dan ditandatangani mereka yang membuat perjanjian tersebut. Pencantuman arbitration clause dalam suatu perjanjian dapat dilakukan sebelum maupun setelah sengketa terjadi. Sehingga dengan adanya pencantuman arbitration clause tersebut dalam perjanjian para pihak, maka memiliki konsekuensi hukum apabila terjadi permasalahan (sengketa) diantara mereka dikemudian hari maupun setelah sengketa terjadi, untuk dapat diselesaikan melalui lembaga non litigasi yaitu badan arbitrase bukan Pengadilan Negeri. Hal tersebut sebagaimana diatur dalam Pasal 1 ayat (1) UU No. 30 tahun 1999 tentang AAPS (Arbitrase dan APS). Ps. 1 ayat (1) mengatur pengertian arbitrase sebagai suatu metode (cara) untuk menyelesaikan sengketa perdata secara non litigasi atas dasar arbitration agreement secara tertulis serta ditandatangani mereka yang berperkara. Dengan demikian Pengadilan Negeri wajib menghormati dan mengakui wewenang serta fungsi arbiter atau majelis arbiter dengan tidak memeriksa sengketa perdata yang diajukan mereka yang telah membuat arbitration agreement. ${ }^{8}$

Dunia perdagangan internasional telah lama mengenal adanya doktrin prinsip competence-competence ini. Sehingga kemudian prinsip ini dijadikan sebagai prinsip yang sangat penting didalam menentukan kewenangan (jurisdiksi) suatu badan arbitrase. ${ }^{9}$ Prinsip ini menyatakan bahwa dalam menyelesaikan sengketa yang terjadi diantara mereka yang membuat perjanjian dengan arbitration clause, dengan adanya prinsip tersebut maka lembaga arbitrase dapat memutus dan menyelesaikan sengketa tersebut serta menyatakan dirinya (badan arbitrase) mempunyai jurisdiksi untuk itu. Jurisdiksi yang dimaksud adalah dalam hal penentuan keabsahan dari perjanjian arbitrase dan klasul arbitrase. Sehingga dengan demikian majelis arbitrase dapat melakukan penilaian mengenai keabsahan perjanjian tersebut. ${ }^{10}$

Mengenai arbitrase ini telah ada pengaturannya dalam UU AAPS No. 30/1999. Dalan UU AAPS pengaturan prinsip competence-competence tidak secara khusus diatur,

\footnotetext{
${ }^{5}$ Memi, Cut. op.cit, p.43

6 Moses, Margaret L. (2012). The Principles and Practice of International Commercial Arbitration. Cambridge : Cambridge U.P p.91

7 Setiawan. (2003). Beberapa Catatan Hukum tentang Klausul Arbitrase. Makalah dalam Kapita Selekta Arbitrase dan Permasalahannya. Jakarta : Mahkamah Agung Republik Indonesia), p. 40

${ }_{8}$ Abdurrasyid, Priyatna. (2002). Arbitrase \& Alternatif Penyelesaian Sengketa-Suatu Pengantar. Jakarta : Fikahati Aneska, p. 93

9 Tweeddale, Andrew, and Tweeddale, Keren (2007). Arbitration of Commercial Disputes : International and English Law and Practice. Oxford : Oxford U.P, p.169

${ }^{10}$ Moses, Margaret L. op.cit, p.92
} 
sehingga menimbulkan kekosongan norma hukum mengenai kewenangan arbitrase menyatakan keabsahan suatu klausul dan perjanjian arbitrase. Prinsip competencecompetence ini terdapat pengaturannya dalam Ps. 18 (1) Peraturan Badan Arbitrase Nasional Indonesia (BANI). Ps. 18 (1) Peraturan BANI mengatur dengan judul : kompetensi-kompetensi. Majelis arbitrase mempunyai hak dalam menyatakan keberatan atas pernyataan bahwa badan arbitrase tersebut tidak mempunyai kewenangan menentukan keabsahan (validity) klausul atau arbitration agreement.

Adanya perjanjian dengan klausul arbitrase maka dengan telah dicantumkannya penyelesaian sengketa dalam suatu perjanjian arbitrase yang memuat ketentuan mengenai pemilihan hukum acara dalam peraturan BANI, sehingga berlakulah ketentuan Pasal 18 ayat (1) Peraturan BANI mengenai kompetensi-kompetensi. Namun adanya contoh kasus antara PT CTPI dengan PT BKB dengan mana telah ada perjanjian dengan klausul arbitrase antara PT CTPI dengan PT BKB untuk menyelesaikan sengketa diantara mereka melalui arbitrase BANI di Jakarta dengan menggunakan hukum acara menurut peraturan BANI. Namun kemudian sengketa antara PT CTPI dengan PR BKB dilakukan penyelesaiannya di Pengadilan Umum (PN). Sengketa berlanjut sampai upaya hukum ke Mahkamah Agung yang dalam pertimbangannya menyatakan bahwa sengketa yang terjadi antara PT CTPI dengan PT BKB merupakan sengketa di luar perjanjian dengan klausul arbitrase.

Permasalahan hukum dalam penelitian ini berkaitan dengan tidak diaturnya kewenangan (jurisdiksi) badan arbitrase dalam hal menentukan apakah dirinya berwenang atau tidak untuk menangani sesuatu sengketa dalam hal ini mengenai keabsahan klausul dan perjanjian arbitrase. Disisi lain mengenai kewenangan arbitrase tersebut telah ada pengaturannya dalam Pasal 18 ayat (1) Peraturan BANI. Dengan demikian terdapat kekosongan norma hukum mengenai prinsip competence-competence di dalam UU No. 30 tahun 1999 megenai kewenangan lembaga arbitrase dalam menyatakan keabsahan klausul dan perjanjian arbitrase. Sehingga hal-hal yang perlu dikaji dalam penelitian ini yaitu :

1. Bagaimanakah pengaturan arbitrase BANI dalam Undang-Undang Nomor 30/1999 tentang Arbitrase dan APS?

2. Apakah ketentuan Pasal 18 ayat (1) Peraturan BANI dapat dijadikan landasan kewenangan BANI dalam menentukan keabsahan klausul dan perjanjian arbitrase?

Adapun tujuan dilakukannya penelitian ini secara umum bertujuan untuk mengetahui serta memahami legalitas kewenangan Badan Arbitrase Nasional Indonesia dalam penerapan prinsip competence-competence. Tujuan khusus dari penelitian ini adalah :

1. Untuk dapat memahami pengaturan arbitrase BANI dalam Undang-Undang Nomor 30/1999 tentang Arbitrase dan APS.

2. Untuk dapat memahami landasan kewenangan BANI dalam menentukan keabsahan klausul dan perjanjian arbitrase?

Pendekatan yang digunakan yaitu pendekatan perundang-undangan, kasus dan analisis konsep hukum.

\section{Metode Penelitian}

Penelitian ini adalah merupakan penelitian hukum normatif yaitu adanya kekosongan norma hukum mengenai prinsip competence-competence di dalam Undang-Undang Nomor 30/1999 tentang Arbitrase dan APS. Jenis pendekatan yang digunakan yaitu pendekatan perundang-undangan, kasus dan analisa konsep hukum. 
Teknik pengumpulan data dalam penelitian ini dilakukan melalui studi kepustakaan. Teknik analisa data secara kualitatif kemudian disajikan secara deskriptif analitis.

\section{Landasan Teoritis}

2.1 Asas otonomi para pihak

Asas otonomi para pihak ini merupakan salah satu asas dalam hukum arbitrase. Asas ini menyatakan adanya kebebasan (otonomi) diantara mereka yang membuat perjanjian dengan klausul arbitrase untuk melakukan pemilihan terhadap penyelesaian sengketa diantara mereka, termasuk apabila pilihan itu jatuh kepada arbitrase. Kebebasan tersebut meliputi kebebasan untuk menentukan hukum acara yang akan digunakan, proses penyelesaian oleh arbitrase serta mengenai jangka waktu penyelesaian sengketa dan lembaga yang berwenang menyelesaikannya. ${ }^{11}$

2.2 Prinsip severability atau pemisahan

Prinsip ini menyatakan bahwa klausul arbitrase yang menjadi bagian dari suatu perjanjian arbitrase harus berlaku sebagai suatu perjanjian yang berdiri sendiri terlepas dari persyaratan yang lainnya dari suatu perjanjian arbitrase sebagaimana ketentuan sebagaimana diatur Pasal 10 UU AAPS. Dengan batalnya suatu perjanjian yang mengandung klausul arbitrase maka tidak secara langsung penyelesaian sengketa yang telah dipilih para pihak dalam klausul arbitrase menjadi tidak sah. ${ }^{12}$

\subsection{Yurisprudensi}

Penerapan prinsip competence-competence ini didalam putusan-putusan hakim dalam beberapa kasus seperti :

1) Kasus antara Joc Oil ( A Bermudian Company) dengan A Soviet Foreign Trade Organization.

2) Kasus antara Dallah Real Estate and Tourism Holding Co. dengan Misnistry of Religious Affair, Goverment of Pakistan (the Trust).

\section{Hasil Dan Pembahasan}

3.1 Pengaturan Badan Arbitrase dalam Undang-Undang Nomor 30 Tahun 1999 tentang Arbitrase dan Alternatif Penyelesaian Sengketa

Badan arbitrase di dalam UU AAPS memiliki pengaturan dalam ketentuan Pasal 1 angka 8 UU AAPS. Pasal 1 angka 8 diatur pengertian lembaga arbitrase sebagai lembaga yang telah ditunjuk oleh mereka yang berselisih untuk memberikan putusannya terhadap perselisihan tertentu. Selain itu dapat pula diminta untuk memberikan suatu pendapat yang mengikat kepada para pihak mengenai suatu hubungan hukum tertentu setelah perselisihan ataupun sebelum perselisihan terjadi.

Mengenai hukum acara yang digunakan arbitrase dalam menyelesaikan perselisihan mendapat pengaturannya dalam Pasal 31 UU AAPS. Pasal 31 ayat (1) mengatur bahwa para pihak diberikan kebebasan untuk mengatur mengenai hukum acara yang akan digunakan dalam memeriksa perselisihan para pihak yang terlebih dahulu harus tertuang dalam suatu perjanjian tertulis, asalkan tidak bertentangan

${ }^{11}$ Khoidin, M. (2007). Hukum Arbitrase Bidang Perdata (Eksistensi, Pengaturan dan Praktek). Surabaya : LaksBang PRESSindo, p.37

${ }^{12}$ Adolf, Huala. (2015). Dasar-Dasar, Teori, Prinsip dan Filosofi Arbitrase. Bandung : Keni Media, p. 165 
dengan aturan dalam UU AAPS. Ayat (2) mengatur bahwa apabila hukum acara yang akan digunakan tidak ditentukan oleh para pihak yang berselisih maka digunakan hukum acara yang ada dalam UU AAPS. Ayat (3) mengatur bahwa setelah hukum acara dipilih maka kesepakatan mengenai jangka waktu dan tempat penyelesaian perselisihan akan ditentukan para pihak. Apabila tidak ada kesepakatan mengenai hal tersebut maka majelis arbitrase akan menentukan sendiri mengenai jangka waktu dan tempat penyelesaian perselisihan. Pasal 31 ayat (1) dan ayat (3) mengisyaratkan adanya asas otonomi para pihak dengan memberi kebebasan kepada para pihak untuk menentukan hukum acara arbitrase serta jangka waktu dan tempat pemeriksaan arbitrase. Dari bunyi ketentuan Pasal 31 ayat (2) tersebut dapat dikatakan bahwa hukum acara yang ditentukan mereka yang bersengketa sebagai ketentuan yang bersifat khusus sedangkan hukum acara yang diatur dalam UU AAPS merupakan hukum acara yang bersifat umum yang dapat diterapkan didalam penyelesaian sengketa antara para pihak. Dari uraian tersebut diatas, pengaturan badan arbitrase dalam hal telah dipilihnya BANI oleh para pihak dalam menyelesaikan perselisihan tertentu dalam hal ini mengenai kewenangan (jurisdiksi) untuk dapat menyelesaikan sengketa arbitrase telah terdapat pengaturannya dalam Ps. 1 angka 8 Undang-Undang AAPS junco Ps. 31.

3.2 Landasan Kewenangan Badan Arbitrase Nasional Indonesia (BANI) dalam Menentukan Keabsahan Suatu Klausul dan Perjanjian Arbitrase

Kewenangan (jurisdiksi) badan arbitrase dalam UU AAPS sebagaimana ketentuan Ps. 3 Undnag-Undang AAPS juncto Ps. 11 UU AAPS. Ps. 3 menegaskan bahwa PN tidak memiliki kewenangan menyelesaikan perselisihan mereka, dalam perjanjian dengan arbitration clause. Demikian pula Ps. 11 lebih menegaskan kembali bahwa meniadakan hak mereka yang membuat perjanjian untuk membawa perselisihannya kepada PN. Pasal 3 juncto Pasal 11 UU AAPS tidak mengatur tentang kewenangan (jurisdiksi) yang berkaitan dengan keberadaan dan keabsahan klausul arbitrase.

Lembaga arbitrase internasional telah memasukan prinsip competencecompetence ke dalam hukum acara lembaga arbitrase seperti Pasal 6 ayat (3) ICC Rules, Ps. 16 (1) UNCITRAL Model Law serta Ps. 23:1 LCIA Rules.13 Terdapat pula pengaturannya dalam hukum nasional nasional dengan mengadopsi UNCITRAL Model Law. ${ }^{14}$ Pasal 16 ayat (1) UNCITRAL Model Law mengatur :

Majelis arbitrase dapat memutuskan jurisdiksinya sendiri, termasuk setiap keberatan sehubungan dengan keberadaan atau keabsahan perjanjian arbitrase. Untuk tujuan itu, klausul arbitrase yang merupakan bagian dari kontrak harus diperlakukan sebagai perjanjian yang terlepas dari ketentuan-ketentuan lainnya dalam kontrak tersebut. Keputusan majelis arbitrase bahwa kontrak tersebut batal tidak akan menyebabkan ketidakabsahan klausul arbitrase. ${ }^{15}$

Bunyi Pasal 16 ayat (1) UNCITRAL Model Law tersebut diatas, mengatur kewenangan pengadilan arbitrase untuk menentukan jurisdiksinya, termasuk menyatakan keberatan apabila ada pihak yang meragukan mengenai keberadaan dan keabsahan klausul arbitrase serta perjanjian arbitrase itu sendiri.

${ }^{13}$ Tweeddale, Andrew, and Tweeddale, Keren. op.cit, p. 170

14 Moses, Margaret L. loc.cit

${ }^{15}$ Adolf, Huala. (2015). op.cit, p. 164 
Penerapan prinsip competence-competence ini dalam praktik di pengadilan :

1) Di Indonesia

Pasal 16 ayat (1) UNCITRAL Model Law mengatur mengenai prinsip competencecompetence dengan menyatakan pengadilan arbitrase dapat menentukan sendiri jurisdiksinya mengenai keabsahan klausul atau perjanjian arbitrase termasuk mengenai adanya keberatan dari pihak lain mengenai hal tersebut. Karenanya menurut Ps. 16 (1) Model Law UNCITRAL, lembaga yang berwenang untuk menentukan keabsahan klausul atau perjanjian arbitrase adalah badan arbitrase bukan pengadilan. ${ }^{16}$ BANI Rules juga mengatur mengenai prinsip tersebut yaitu dalam Ps. 18 (1) mengatur mengenai Kompetensi-kompetensi. Majelis arbitrase memiliki hak untuk menyatakan keberatan atas adanya pernyataan bahwa dirinya tidak memiliki kewenangan, yang dimaksud kewenangan disini yaitu berkaitan dengan validitas (keabsahan) arbitration agreement.

2) Di Luar Negeri

a) Sengketa antara Joc Oil vs SNE

Sengketa bermula dari ditandatanganinya suatu kontrak jual beli atas ribuan juta ton minyak antara suatu perusahaan Bermuda, AS (Joc Oil) dengan suatu organisasi perdagangan luar negeri Soviet (SNE). Setelah terjadi sengketa, perkara ini diajukan ke lembaga arbitrase Soviet Union dan arbitrase tersebut memutuskan bahwa berdasarkan kontrak yang telah disepakati para pihak, Joc Oil telah menyetujui untuk membayar kepada SNE sejumlah US\$200,000,000. Akan tetapi, berdasarkan pembelaan dari pihak Joc Oil dikatakan bahwa putusan arbitrase Soviet Union tersebut tidak dapat dilaksanakan di negara bagian Bermuda, dengan alasan antara lain karena perjanjian di antara para pihak tidak sah dan karena itu tidak dapat diselesaikan secara arbitrase. Karena kontra para pihak hanya ditandatangani oleh satu orang pejabat saja sedangkan hukum Soviet mengatur bahwa kontrak para pihak harus ditandatangani oleh dua orang pejabat. Hal tersebut membuat kontrak menjadi tidak sah. ${ }^{17}$

Pengadilan tingkat pertama Negara Bagian Bermuda menerima argumen bahwa kontrak antara para pihak tidak sah. Kemudian dikuatkan oleh Pengadilan Tinggi Negara Bagian Bermuda yang beralasan bahwa kontrak yang tidak sah bukan berarti perjanjian para pihak yang bersengketa dianggap tidak ada (non existent). Hal tersebut sebagaimana diklaim pihak Joc Oil. Sehingga dalam hal ini Pengadilan Tinggi Negara Bagian Bermuda menyatakan bahwa meskipun perjanjian pokok dinyatakan batal, perjanjian arbitrase tetap exist (berlaku). ${ }^{18}$

Secara logika dapat dikatakan bahwa meskipun kebanyakan institusi dan hukum nasional membuat konsep aturan-aturan tentang keterpisahan (seperability) arbitrase untuk mempertahankan keabsahan klausul arbitrase adalah bagian dari non-existent contract, akan tetapi nonexistent contract tersebut tidak dapat diartikan sebagai never existed, melainkan harus diartikan sebagai ceased to exist. Batalnya kontrak tidak membuat Pengadilan Arbitrase berhenti untuk memeriksa dan memutus sengketa para pihak. Namun apabila kontrak sejak semula dianggap tidak

\footnotetext{
${ }^{16}$ Memi, Cut. op.cit, p. 47

17 Ibid, p. 48-49

${ }^{18}$ Ibid, p. 49
} 
pernah ada secara keseluruhan, maka dianggap tidak pernah ada suatu kontrak. Dengan demikian, Pengadilan Arbitrase dapat mempunyai yurisdiksi atau kewenangan untuk dapat menyatakan kontrak tidak sah adanya atau no valid existed. ${ }^{19}$

b) Sengketa Dallah Real Estate \& Tourim Holding Co vs Ministry of Religious Affair, Government of Pakistan (The Trust)

Prinsip competence-competence menyatakan bahwa berdasarkan sengketa yang diajukan kepada badan arbitrase ia berkompeten untuk itu. Namun dalam praktek pengadilan bisa saja menetapkan di kemudian hari bahwa tribunal arbitrase tidak mempunyai yurisdiksi dan menyatakan arbitrase tidak berwenang. Hal ini terjadi pada kasus Dallah Real Estate $\mathcal{E}$ Tourism Holding Co vs Ministry of Religious Affair, Government of Pakistan (The Trust). Pengadilan Inggris yang pernah memeriksa kasus Dallah Real Estate $\mathcal{E}$ Tourism Holding Co v. Ministry of Religious Affair, Government of Pakistan (the "Trust"), dalam perjanjian para pihak telah disepakati bahwa untuk penyelesaian sengketa yang terjadi akan diselesaikan melalui arbitrase ICC yang berkedudukan hukum di Paris, akan tetapi dalam klausul arbitrase tersebut tidak dicantumkan secara eksplisit tentang hukum mana yang akan diberlakukan (governing law) terhadap perjanjian para pihak. Atas permasalahan tersebut, Pengadilan Inggris menolak pelaksanaan eksekusi putusan arbitrase ICC di Pengadilan Negara Inggris. ${ }^{20}$

Setelah perkara ini diajukan ke ICC, dan oleh karena tidak adanya governing law di dalam perjanjian para pihak, maka tribunal arbitrase ICC menerapkan prinsip-prinsip sebagaimana yang ditentukan dalam hukum transnational. Atas dasar aturan dari hukum transnasional, tribunal arbitrase berpendapat bahwa Pakistan adalah pihak dalam perjanjian arbitrase para pihak dan tribunal arbitrase ICC menyatakan bahwa berdasarkan sengketa yang diajukan kepadanya, ICC berkompeten untuk itu. Akan tetapi, ketika permohonan pelaksanaan eksekusi putusan arbitrase ICC tersebut diajukan ke Pengadilan Inggris pada bulan Januari 2009, Hakim Pengadilan Tinggi Inggris (English High Court Judgment) menolak untuk melaksanakan putusan arbitrase ICC tersebut, atas dasar bahwa perjanjian arbitrase di antara para pihak tidak sah (no valid), karena hukum yang seharusnya diterapkan oleh arbitrase adalah hukum Perancis (tempat di mana putusan arbitrase diputuskan), bukan berdasarkan transnasional law yang digunakan oleh tribunal arbitrase. ${ }^{21}$ Kemudian atas penolakan pelaksanaan putusan arbitrase ICC di Pengadilan Negara Inggris maka diajukan banding ke Mahkamah Agung (Supreme Court). Akan tetapi, pada tanggal 4 November 2010, Supreme Court justru menegaskan bahwa mereka mengakui doktrin prinsip competence-competence, akan tetapi dengan doktrin itu, tidak berarti bahwa arbitrator-arbitrator saja sebagai satu-satunya hakim (solo judges) yang mempunyai kewenangan, tetapi pengadilan juga mempunyai kewenangan, dan apabila suatu tindakan dibatalkan melalui suatu putusan, maka pengadilan berhak untuk tidak saja mengkaji ulang tentang yurisdiksi arbitrase, tetapi juga mempunyai kewenangan yang luas untuk membuka

19 Ibid

20 Ibid, p. 49-50

${ }^{21}$ Ibid, p. 50 
kembali fakta kasus dalam rangka menentukan secara independen, apakah suatu perjanjian arbitrase sah adanya. Supreme Court atau Mahkamah Agung akhirnya menyimpulkan bahwa semestinya hukum Perancislah yang diterapkan oleh tribunal arbitrase dalam kasus ini, bukan transnasional law sehingga dengan alasan tersebut akhirnya pelaksanaan eksekusi atas putusan arbitrase ICC dalam kasus Dallah tidak dapat dilaksanakan. ${ }^{22}$

Dari contoh kasus diatas, prinsip competence-competence mendapatkan pengaturannya dalam Pasal 18 ayat (1) Peraturan BANI. Dibawah judul kompetensi-kompetensi. Majelis arbitrase memiliki hak untuk menyatakan keberatan atas pernyataan bahwa ia tidak memiliki kewenangan terkait dengan penentuan keabsahan klausul atau perjanjian arbitrase itu sendiri, apabila terdapat alasan untuk itu. Dari Pasal 18 ayat (1) Peraturan BANI, menandakan bahwa BANI memiliki hukum acara arbitrasenya sendiri.

Penerapan prinsip competence-competence ini dibatasi oleh ketentuan Pasal 31 UU AAPS sebagai aturan yang bersifat umum mengenai arbitrase. Pasal 31 ayat (1) mengatur bahwa para pihak diberikan kebebasan untuk memutuskan hukum acara arbitrase yang digunakan untuk memeriksa perselisihan diantara mereka. Yang tentunya sebelumnya telah dibuat perjanjian tertulis mengenai hal itu. Kebebasan tersebut diartikan sebagai bebas sepanjang tidak bertentangan dengan UU AAPS. Maksudnya bahwa pembatasan tersebut diatur dalam Pasal 9 UU AAPS. Pasal 9 mengatur :

1) Kesepakatan tertulis mengenai penyelesaian sengketa melalui arbitrase.

2) Apabila para pihak tidak dapat membubuhkan tandatangan dalam perjanjian arbitrase maka perjanjian harus dibuat dengan akta notaris.

3) Perjanjian penyelesaian sengketa melalui arbitrase harus memuat antara lain : masalah yang dipersengketakan para pihak, nama lengkap dan tempat tinggal para pihak serta arbitor atau majelis arbitrase, tempat penyelesaian sengketa, jangka waktu penyelesaian sengketa, nama sekretaris, kesediaan menanggung biaya penyelesaian sengketa.

4) Akibat dari tidak dipenuhinya ketentuan dalam angka 3 maka perjanjian "batal demi hukum".

Dari penjelasan tersebut diatas, maka ketentuan Pasal 18 ayat (1) Peraturan BANI dapat dijadikan legalitas kewenangan BANI didalam menyelesaikan sengketa arbitrase termasuk didalam mempunyai hak untuk menyatakan keberatan atas pernyataan bahwa BANI tidak mempunyai kewenangan terkait dengan penentuan keabsahan klausul atau perjanjian arbitrase. Namun dengan syarat bahwa adanya kesepakatan tertulis mengenai pemilihan untuk menyelesaikan sengketa melalui arbitrase diantara para pihak yang bersengketa. Termasuk kesepakatan mengenai hukum acara yang diberlakukan (governing law) untuk menyelesaikan sengketa. Serta harus dituangkan di dalam perjanjian mengenai masalah yang dipersengketakan para pihak untuk dapat diselesaikan melalui arbitrase. Meskipun telah ada perjanjian mengenai penyelesaian sengketa melalui arbitrase serta telah dipenuhinya ketentuan dalam Pasal 9 UU AAPS tersebut, apabila salah satu pihak membawa perkaranya ke Pengadilan Negeri maka dengan adanya asas pemisahan tidak menghentikan pengadilan arbitrase untuk memeriksa serta memutuskan sengketa arbitrase termasuk didalamnya mengenai sengketa untuk menentukan keabsahan klausul atau perjanjian arbitrase.

${ }^{22}$ Ibid, p. 50-51 


\section{Kesimpulan}

1) Pengaturan badan arbitrase BANI dalam UU No. 30 Tahun 1999 tentang Arbitrase dan Alternatif Penyelesaian Sengketa telah diatur dalam ketentuan Pasal 1 angka 8 UU AAPS juncto Pasal 31 UU AAPS.

2) Ketentuan Pasal 18 ayat (1) Peraturan BANI dapat dijadikan landasan legalitas kewenangan BANI dalam menentukan keabsahan perjanjian arbitarse, apabila perjanjian para pihak untuk menyelesaikan sengketa melalui arbitrase tidak "batal demi hukum" atau dianggap tidak pernah ada secara keseluruhan.

\section{Daftar Pustaka / Daftar Referensi}

\section{Buku}

Adolf, H. (2015). Dasar-Dasar, Teori, Prinsip dan Filosofi Arbitrase. Bandung: Keni Media.

Abdurrasyid, P. (2002). Arbitrase E Alternatif Penyelesaian Sengketa - Suatu Pengantar, Jakarta : Fikahati Aneska.

Khoidin, M. (2017). Hukum Arbitrase Bidang Perdata (Eksistensi, Pengaturan dan Praktek), Surabaya : LaksBang PRESSindo.

Memi, C. (2017). Arbitrase Komersial Internasional Penerapan Klausul dalam Putusan Pengadilan Negeri. Jakarta : Sinar Grafika.

Moses, M. L. (2012). The Principles and Practice of International Commercial Arbitration, Cambridge : Cambridge U.P.

Park, W. (1997). When and Why Arbitration Matters. dalam Hartwell, M. B. G . (1997). The Commercial Way to Justice (ed).

Redfern, A. and Hunter, M. ( 2004 ). Law and Practice of International Commercial Arbitration (Fourth Edition), Sweet \& Maxwell.

Tweeddale, A. and Tweeddale, K. (2007). Arbitration of Commercial Disputes: International and English Law and Practice. Oxford : Oxford U.P.

\section{Jurnal}

Adolf, H. ( 2014). Sengketa Penanaman Modal : Yurisdiksi Badan Arbitrase ICSID. Arbitration Newsletter BANI. Vol 6 No. 1. Jakarta : March 2014. 
P-ISSN: 2502-8960, E-ISSN: 2502-7573

\section{Makalah}

Setiawan. (2003). Beberapa Catatan Hukum tentang Klausul Arbitrase. Makalah dalam Kapita Selekta Arbitrase dan Permasalahannya. Jakarta : Mahkamah Agung Republik Indonesia). 